\title{
Keanekaragaman Semut Musuh Alami (Hymenoptera: Formicidae) pada Perkebunan Kelapa Sawit Rakyat di Kecamatan Timpeh Kabupaten Dharmasraya
}

\author{
Ridho Romarta ${ }^{1}$, Yaherwandi², dan Siska Efendi ${ }^{3 *}$ \\ ${ }^{1}$ Program Studi Agroekoteknologi, Fakultas Pertanian, \\ Kampus III Universitas Andalas Dharmasraya \\ Jl. Lintas Sumatera Km 4 Pulau Punjung, Dharmasraya (27612), Indonesia \\ ${ }^{2}$ Program Studi Proteksi Tanaman, Jurusan Hama dan Penyakit Tumbuhan, Fakultas Pertanian, \\ Universitas Andalas, Limau Manis, Padang (25163), Indonesia \\ ${ }^{3}$ Program Studi Agroekoteknologi, Fakultas Pertanian, \\ Kampus III Universitas Andalas Dharmasraya \\ Jl. Lintas Sumatera Km 4 Pulau Punjung, Dharmasraya (27612), Indonesia \\ *Alamat korespondensi: siskaefendi@agr.unand.ac.id
}

\begin{abstract}
Diversity of ant on smallholder of oil palm plantation in Timpeh District, Dharmasraya Regency

The ecosystem of oil palm plantation consists of various types of ferns, weeds, grasses and insects in which forming a complex ecosystem. Insects from family Formicidae are interesting topics to studied, one of them is ant. The ants in the oil palm ecosystem have many roles including as pollinators, predators, decomposers and herbivores. The research was carried out in the smallholder oil palm plantations in Nagari Panyubarangan and Tabek, Timpeh District, Dharmasraya Regency, West Sumatera from September 2018 to February 2019. The purpose of this research was to study the diversity of ants in the smallholder oil palm plantations. A field survey using purposive random sampling method was conducted. Sampling was done by hand collecting, bait trap and pitfall trap methods. The ants' identification was carried out at the Animal Taxonomy Laboratory, Department of Biology, Faculty of Mathematics and Natural Sciences, Andalas University, Padang. Analysis of diversity was conducted using the Shannon-Wienner's Index and Simpson's Evenness Index. The result demonstrated ant diversity index ranged from 1.83 to 2.08. The total ants collected were 8,763 individuals, consisted of 14 genera and 29 species. The most dominant species was Anopolepis gracilipes followed by Crematogaster borneensis and Monomorium floricola with the important value index of 0.57 . These ants were categorized as predator for several oil palm pests.
\end{abstract}

Keywords : Anopolepis gracilipes, Elaeis guineensis, Hymenoptera, Identification

\begin{abstract}
ABSTRAK
Ekosistem perkebunan kelapa sawit terdiri dari berbagai jenis paku-pakuan, gulma, rerumputan dan serangga yang membentuk suatu ekosistem yang kompleks. Serangga dari golongan Formicidae merupakan aspek yang menarik untuk dikaji salah satunya yaitu semut. Pada ekosistem kelapa sawit, semut memiliki berbagai peran diantaranya sebagai penyerbuk, predator, pengurai dan herbivora. Penelitian ini dilaksanakan di perkebunan kelapa sawit rakyat di Nagari Panyubarangan dan Tabek, Kecamatan Timpeh, Kabupaten Dharmasraya, Sumatera Barat pada bulan September 2018 sampai Februari 2019. Penelitian ini bertujuan untuk mengetahui keanekaragaman semut pada ekosistem perkebunan kelapa sawit rakyat. Percobaan dilakukan dengan metode survei menggunakan metode Purposive Random Sampling. Pengambilan sampel menggunakan metode Hand Collecting, Bait Trap, dan Pitfall Trap. Identifikasi dilakukan di Laboratorium Taksonomi Hewan, Jurusan Biologi, Fakultas MIPA, Universitas Andalas, Padang. Analisis keanekaragaman menggunakan indeks Shannon-Wienner dan indeks kemerataan
\end{abstract}


Simpson. Indeks keanekaragaman berkisar antara 1,83 sampai dengan 2,08. Total semut yang dikoleksi sebanyak 8.763 individu yang terdiri dari 14 genus, dan 29 spesies. Spesies yang paling dominan adalah Anoplolepis gracilipes diikuti Crematogaster borneensis dan Monomorium floricola dengan Indeks Nilai Penting yakni 0,57. Masing-masing spesies semut tersebut berperan sebagai predator beberapa hama kelapa sawit.

Kata Kunci : Anoplolepis gracilipes, Elaeis guineensis, Hymenoptera, Identifikasi

\section{PENDAHULUAN}

Sumatera Barat merupakan salah satu Provinsi penghasil kelapa Sawit di Indonesia. Dari 19 kabupaten/kota yang ada di Sumatera Barat tercatat hanya 10 kabupaten dan 3 kota yang membudidayakan kelapa sawit. Produksi kelapa sawit di Sumatera Barat pada periode 2013-2017 yakni sebanyak 426.476 ton, 450.941 ton, 459.793 ton, 1.184.692.79 ton dan 1.184.692.79 ton. Kabupaten penghasil kelapa sawit terbesar di Sumatera Barat yakni Kabupaten Pasaman Barat dan Kabupaten Dharmasraya, dengan total produksi pada tahun 2017 masing-masing sebanyak 529.839.72 ton dan 193.059.43 ton (BPS Sumbar, 2017). Berbagai upaya dilakukan pemerintah Sumatera Barat untuk meningkatkan produksi kelapa sawit, salah satu upaya tersebut melalui program ekstensifikasi dengan menambah luas areal perkebunan kelapa sawit. Hal ini dilakukan oleh pemerintah Kabupaten Dharmasraya yang pada tahun 2014 menambah luas areal perkebunan kelapa sawit sebesar 612.31 ha (BPS Dharmasraya, 2016).

Kabupaten Dharmasraya khususnya Kecamatan Timpeh merupakan wilayah yang mayoritas komoditi pertaniannya adalah perkebunan kelapa sawit dengan luas $7.161 \mathrm{Ha}$. Kelapa sawit menjadi komoditi unggulan di Kecamatan Timpeh. Hal ini dapat dibuktikan melalui hasil produksi perkebunan kelapa sawit rakyat pada periode 2015-2016 yakni 18.522 ton dan 5.250.40 ton. Perkebunan kelapa sawit tidak hanya ditanam pada perkebunan yang diusahakan oleh negara, tetapi juga perkebunan rakyat dan swasta. Salah satu contohnya adalah perkebunan kelapa sawit rakyat di Kecamatan Timpeh Kabupaten Dharmasraya. Komoditi kelapa sawit merupakan komoditi yang hasil produksinya lebih tinggi dibandingkan dengan komoditi lainnya (BPS Dharmasraya, 2016). Namun demikian, seperti pada budidaya tanaman lainnya beberapa faktor menjadi kendala pada budidaya kelapa sawit, salah satunya adalah keberadaan hama yang menyerang kelapa sawit.
Dilaporkan bahwa serangan hama mampu menyebabkan penurunan produksi kelapa sawit. Ulat api dan ulat kantung merupakan hama penting kelapa sawit yang mampu menyebabkan kehilangan hasil yang signifikan (Kalshoven, 1981). Serangan hama tersebut mampu menurunkan produksi sebesar $69 \%$ pada tahun pertama kemunculannya dan bertambah hingga 96\% setelah tahun kedua (Simanjuntak dkk.., 2011). Serangan hama kelapa sawit dimulai dari masa pembibitan hingga tanaman menghasilkan, serangan lebih lanjut mampu menyebabkan kematian tanaman (Corley \& Tinker, 2003). Berkaitan dengan hal itu maka diperlukan teknik pengendalian yang sesuai dengan kesepakatan Roundtable on Sustainable Palm Oil (RSPO) yakni pengendalian hayati yang menerapkan teknik pengendalian serangga hama dengan memanfaatkan musuh alami (Fricke, 2008). Ekosistem perkebunan kelapa sawit disusun oleh berbagai macam organisme seperti tumbuhan pakupakuan, gulma, rerumputan dan tumbuhan liar lainnya serta berbagai macam serangga yang hidup didalamnya, baik itu serangga yang bersifat sebagai hama maupun musuh alami. Salah satu organisme yang berperan sebagai musuh alami hama di perkebunan kelapa sawit adalah semut predator. Salah satu spesies semut yang berperan sebagai musuh alami ini adalah semut gila (Anoplolepis gracilipes). Semut gila membentuk koloni besar pada perkebunan kelapa sawit dan dapat memengaruhi sebagian besar arthropoda seperti larva kumbang tanduk dan vetebrata yang ada di perkebunan kelapa sawit (Bruhl, 2008).

Semut adalah serangga sosial yang merupakan kelompok serangga yang termasuk ke dalam ordo Hymenoptera dan famili Formicidae. Organisme ini terkenal dengan koloni dan sarangsarangnya yang teratur. Semut dibagi menjadi semut pekerja, prajurit, pejantan dan ratu. Organisme ini memiliki kurang lebih 12.000 spesies yang tersebar di dunia, dan sebagian besar berada di kawasan tropis (Suhara, 2009). Pada perkebunan kelapa sawit spesies semut diperkirakan berjumlah sekitar 110 spesies (Marshall, 2013). Beberapa peranan dari semut adalah sebagai dekomposer, penyerbuk, 
pembuat airator tanah, dan predator (Tawatao, 2014). Dengan peranan yang cukup banyak semut hampir tersebar di semua habitat salah satunya adalah pada ekosistem kelapa sawit (Fitria, 2013). Pada ekosistem ini semut memiliki beberapa peranan diantaranya adalah sebagai penyerbuk, predator, pengurai dan herbivora (Falahudin, 2013). Salah satu manfaat semut pada perkebunan kelapa sawit adalah sebagai musuh alami atau predator untuk hama ulat api dan ulat kantung.

Semut merupakan hewan yang sangat sensitif terhadap perubahan dan gangguan yang ada pada suatu habitat. Perubahan serta gangguan habitat mampu mengubah komposisi spesies semut yang ada sehingga berpengaruh terhadap perubahan interaksi tropik dan jaring makanan yang ada pada ekosistem tersebut (Philpott et al., 2010). Rubiana (2014) menyatakan bahwa modifikasi serta transformasi habitat dari hutan menjadi perkebunan karet dan kelapa sawit menyebabkan perubahan terhadap struktur komunitas semut. Alamsari (2014) melaporkan bahwa keanekaragaman semut pada perkebunan kelapa sawit dinilai lebih tinggi dibanding perkebunan karet, hutan sekunder dan hutan primer serta didominasi semut predator dan omnivor. Keberadaan semut predator dan omnivor pada suatu ekosistem berpotensi untuk menekan populasi serangga hama karena semut termasuk predator yang mempunyai kisaran mangsa yang cukup luas. Penelitian ini bertujuan untuk mempelajari keanekaragaman semut dan mengetahui spesies yang paling dominan pada perkebunan kelapa sawit rakyat di Kecamatan Timpeh Kabupaten Dharmasraya. Hasil penelitian yang diperoleh akan berguna sebagai informasi potensi pemanfaatan semut di perkebunan kelapa sawit sebagai musuh alami hama serta informasi tentang ekosistem lingkungan yang mendukung kelimpahan dan keanekaragaman spesies semut di lokasi penelitian.

\section{METODE PENELITIAN}

\section{Penentuan Lokasi Penelitian dan Tanaman Sampel}

Penentuan lokasi penelitian menggunakan metode survey dengan penentuan tanaman sampel secara Purposive Random Sampling. Lokasi yang digunakan ialah lahan perkebunan kelapa sawit rakyat dengan varietas Simalungun dan luas $\pm 1 \mathrm{Ha}$. Umur tanaman pada masing-masing lahan yakni lahan pertama dan kedua terdapat di Nagari Panyubarangan, dengan umur tanaman pada kedua lahan tersebut yakni 18 dan 8 tahun. Lahan ketiga dan keempat terdapat di Nagari Tabek, dengan umur tanaman pada kedua lahan tersebut yakni 20 tahun. Pada masing-masing nagari dipilih sebanyak dua kebun dengan jarak antar kebun minimal 500 m, setiap kebun diambil sebanyak 10 tanaman sampel. Sehingga didapatkan total tanaman sampel keseluruhan berjumlah sebanyak 40 batang. Tanaman sampel ditentukan secara acak sistematis, pada setiap baris diambil satu batang kelapa sawit sebagai tanaman sampel, antar sampel berjarak $18 \mathrm{~m}$, sehingga didapatkan di masing-masing lokasi penelitian sebanyak 10 tanaman sampel. Pada tanaman sampel yang sudah ditentukan, dilakukan pengambilan serangga contoh sebanyak 3 kali, dengan interval 15 hari.

\section{Pengambilan Serangga Contoh}

Pengambilan sampel dilakukan dengan menggunakan tiga metode yakni koleksi langsung, pitfall trap dan bait trap. Pertama, untuk mengoleksi semut yang terdapat pada tanaman sampel dilakukan dengan metode koleksi langsung. Semut yang terdapat pada tanaman sampel dikoleksi secara langsung dengan menggunakan tangan selama 15 menit. Kedua, untuk mengoleksi semut predator yang aktif di permukaan tanah digunakan perangkap pitfall. Perangkap pitfall adalah perangkap berbentuk gelas dengan diameter bagian atas yakni $15 \mathrm{~cm}$ sedangkan diameter bagian bawah $8 \mathrm{~cm}$. Tinggi perangkap $20 \mathrm{~cm}$. Perangkap tersebut dipasang dalam tanah dengan posisi permukaan sejajar dengan permukaan tanah yang berada $30 \mathrm{~cm}$ dari pangkal tanaman sampel, sebanyak satu buah perangkap pertanaman sampel. Perangkap diisi dengan air yang dicampur dengan deterjen untuk menambah berat masa air sebanyak $1 / 3$ volume perangkap agar semut yang terperangkap ke dalam pitfall langsung tenggelam. Perangkap yang sudah dipasang, dibiarkan selama 24 jam. Ketiga, metode bait trap dengan umpan berupa sarden yang diletakkan dalam plastik. Plastik berisi umpan diikatkan pada tanaman sampel sebanyak satu buah umpan pertanaman sampel dan dibiarkan selama 60 menit. Semut yang terkoleksi disimpan dalam botol koleksi yang telah diisi dengan alkohol 96\% untuk dilakukan identifikasi di laboratorium.

\section{Identifikasi Semut}

Semut yang telah dikoleksi pada lokasi penelitian selanjutnya dilakukan tahap identifikasi pada semut tersebut. Identifikasi dilakukan di laboratorium. Identifikasi semut dilakukan sampai tingkat spesies, mengacu pada Antwiki (2017). 


\section{Analisis Data}

Data yang telah diperoleh digunakan untuk menganalisis indek keanekaragaman ShannonWeiner ( $\left.H^{\prime}\right)$ dan indeks kemerataan Simpson menggunakan aplikasi Past 3.

\section{HASIL DAN PEMBAHASAN}

\section{Kelimpahan Semut Berdasarkan Lokasi Penelitian}

Total semut yang dikoleksi selama penelitian sebanyak 8.763 individu yang terdiri dari 14 genus dan 29 spesies. Kelimpahan berdasarkan lokasi yakni pada Nagari Panyubarangan didapatkan sebanyak 4.506 individu, 23 spesies dan 11 genus. Pada lahan 1 didapatkan sebanyak 2.230 individu, 19 spesies dan 10 genus. Pada lahan 2 didapatkan sebanyak 2.276 individu, 19 spesies dan 10 genus. Pada Nagari Tabek didapatkan sebanyak 4.257 inividu, 26 spesies dan 14 genus. Pada lahan 1 didapatkan sebanyak 2.313 individu, 23 spesies dan 11 genus. Pada lahan 2 didapatkan sebanyak 1.944 individu, 21 spesies dan 13 genus (Tabel 1).

Tabel 1. Kelimpahan semut berdasarkan lokasi penelitian

\begin{tabular}{|c|c|c|c|c|c|}
\hline \multirow{2}{*}{ Genus } & \multirow{2}{*}{ Spesies } & \multicolumn{2}{|c|}{ Panyubarangan } & \multicolumn{2}{|c|}{ Tabek } \\
\hline & & Lahan 1 & Lahan 2 & Lahan 1 & Lahan 2 \\
\hline Anoplolepis & gracilipes Smith, 1857 & 1016 & 399 & 849 & 492 \\
\hline \multirow[t]{2}{*}{ Camponotus } & arrogans Smith,1858 & 0 & 2 & 47 & 3 \\
\hline & kutteri Forel, 1915 & 0 & 0 & 1 & 0 \\
\hline \multirow[t]{3}{*}{ Crematogaster } & borneensis Andre, 1896 & 26 & 486 & 145 & 573 \\
\hline & longipilosa Forel, 1907 & 38 & 136 & 164 & 204 \\
\hline & rogenhoferi Mayr, 1879 & 0 & 94 & 1 & 23 \\
\hline Diacamma & geometricum Smith, 1857 & 0 & 0 & 0 & 2 \\
\hline Dolichoderus & affinis Emery, 1889 & 0 & 0 & 0 & 1 \\
\hline Leptogenys & aspera Andre, 1889 & 53 & 7 & 34 & 18 \\
\hline Monomorium & floricola Jerdon, 1851 & 204 & 345 & 282 & 104 \\
\hline Nylanderia & nylanderia sp01 Emery, 1906 & 0 & 0 & 0 & 2 \\
\hline \multirow[t]{2}{*}{ Odontomachus } & $\begin{array}{l}\text { minangkabau Satria , Kurushima, } \\
\text { Herwina, Yamane \& Eguchi, } 2015\end{array}$ & 2 & 1 & 33 & 19 \\
\hline & similimus Smith, 1858 & 14 & 14 & 11 & 19 \\
\hline \multirow[t]{2}{*}{ Odontoponera } & denticulata Smith, 1858 & 230 & 80 & 379 & 149 \\
\hline & transversa Smith, 1857 & 18 & 7 & 28 & 46 \\
\hline Oecophylla & smaragdina Fabricius, 1775 & 88 & 0 & 25 & 0 \\
\hline \multirow[t]{6}{*}{ Pheidole } & upeneci Forel, 1913 & 306 & 364 & 49 & 0 \\
\hline & aglae Forel, 1913 & 0 & 0 & 2 & 0 \\
\hline & fervens Smith, 1858 & 9 & 1 & 3 & 4 \\
\hline & incerta Smith, 1863 & 172 & 0 & 140 & 75 \\
\hline & inornata Eguchi, 2001 & 5 & 44 & 1 & 10 \\
\hline & sayapensis Eguchi, 2001 & 40 & 284 & 89 & 167 \\
\hline \multirow[t]{4}{*}{ Polyrhachis } & abdominalis Smith, 1858 & 5 & 6 & 11 & 7 \\
\hline & alphena Smith, 1860 & 1 & 0 & 0 & 0 \\
\hline & amana Smith, 1861 & 0 & 0 & 1 & 0 \\
\hline & illaudata Walker, 1859 & 2 & 2 & 17 & 16 \\
\hline \multirow[t]{3}{*}{ Tetraponera } & laeviceps Smith, 1859 & 1 & 0 & 0 & 0 \\
\hline & polita Ward, 2001 & 0 & 3 & 1 & 10 \\
\hline & rufonigra Jerdon, 1851 & 0 & 1 & 0 & 0 \\
\hline
\end{tabular}

Berdasarkan Tabel 1 dapat dilihat bahwa spesies $A$. gracilipies merupakan spesies yang memiliki tingkat kelimpahan tertinggi diikuti $C$. borneensis dan $M$. floricola. A. gracilipes merupakan spesies "tramp" yakni kelompok semut yang beradaptasi dengan baik pada lingkungan manusia dan mampu menyesuaikan diri terhadap daerah yang banyak aktivitas manusia salah satunya perkebunan kelapa sawit. Semakin tinggi tingkat gangguan habitat, keanekaragaman maupun keberadaan spesies semut ini cenderung semakin meningkat. Habitat dengan intensitas gangguan tinggi, seperti perumahan, pantai, perkebunan dan taman, hanya dapat memfasilitasi keberadaan spesies 
semut tramp yang mampu beradaptasi terhadap gangguan manusia (Gibb \& Hochuli, 2003).

A. gracilipes memiliki karakter sangat agresif terhadap spesies semut lain dan mudah terlibat dalam perkelahian mematikan (Drescher et al., 2011). Disamping mampu beradaptasi pada habitat terganggu spesies semut tersebut memiliki jumlah yang lebih banyak dibandingkan spesies semut lainnya, juga menyebabkan hilangnya spesies semut yang lain karena kalah berkompetisi (Holway et al., 2002). Semakin dominannya $A$. gracilipes pada suatu lahan akan berpengaruh terhadap persentase kehadiran semut lainnya disebabkan karena sifat dari spesies semut ini merupakan semut predator. Spesies A. gracilipes berperan sebagai semut predator pada perkebunanan kelapa sawit. Pada beberapa kasus, spesies $A$. gracilipes ditemukan sebagai pemangsa serangga herbivora seperti ulat api, ulat kantung dan belalang yang berpotensi menjadi hama bagi tanaman perkebunan (Perfecto \& Vandermeer, 2002). Hal ini menguntungkan bagi tanaman kelapa sawit karena dapat mengurangi hama tersebut. $C$. borneensis dan $M$. floricola merupakan spesies terbanyak ditemukan setelah $A$. gracilipes, spesies ini banyak di terdapat pada sela pelepah tanaman kelapa sawit dan pada bagian pucuk, bawah daun serta bunga dari gulma harendong bulu (Clidemia hirta). C. borneenses dan $M$. floricola merupakan semut omnivora yang memakan embun madu yang ada pada vegetasi bawah yakni bunga dari harendong bulu.

Berdasarkan hasil penelitian ini terdapat beberapa spesies yang hanya ditemukan pada satu lokasi salah satunya $P$. aglae yang hanya ditemukan pada Lahan 1 di Nagari Tabek. Hal ini disebabkan keberadaan dari $A$. gracilipes sebagai spesies tramp yang bersifat invasif lebih mendominasi dan menguasai daerah tersebut, sehingga keberadaannya pada ekosistem tersebut menjadi lebih sedikit. Menurut Latumahina (2011), kelompok semut tramp memiliki kemampuan berpindah dan membuat sarang dengan mudah. Berbeda dengan spesies yang jarang ditemukan. Hal ini diduga karena spesies yang jarang ditemukan ini hanya ditemukan pada ekosistem dengan faktor iklim yang pas untuk kehidupan spesies tersebut dan menyediakan sumber makanan yang tersedia seperti embun madu, nektar bunga dari vegetasi sekitar atau senyawa folatil yang dihasilkan bunga tanaman kelapa sawit yang dapat mengundang spesies tertentu. Kelimpahan dan keanekaragaman semut pada suatu lokasi juga sangat tergantung pada kondisi lingkungan, dimana semut akan mengalami perubahan kehadiran, vitalitas dan respons apabila terjadi gangguan dalam lingkungan tersebut

Beberapa faktor lingkungan yang diduga sangat berpengaruh terhadap kelimpahan dan keanekaragaman semut pada areal pertanian adalah intensitas cahaya matahari, angin, air, musim, pola makan, kompetisi interspesifik, variasi ketersediaan sumber makanan, kualitas habitat dan aktivitas manusia (Bruhl \& Linsenmair, 1998). Variasi kehidupan semut di dalam ekosistem juga dapat dipengaruhi oleh kondisi iklim mikro seperti faktor suhu dan kelembaban udara. Menurut Riyanto (2007) kisaran suhu $25-33^{\circ} \mathrm{C}$ merupakan suhu optimal dan toleran bagi aktifitas semut di daerah tropis. Lokasi penelitian memiliki tingkat kelembaban yang sedang dan suhu yang optimal yakni berkisar antara $31-33^{\circ} \mathrm{C}$ seperti halnya dengan hutan memiliki tingkat keanekaragaman semut yang tinggi.

Umur tanaman kelapa sawit juga sangat memengaruhi jumlah keberadaan semut baik semut herbivor dan predator. Semakin produktif umur tanaman, maka memungkinkan untuk keberadaan serangga herbivor dalam jumlah yang banyak karena ketersediaan sumber makanannya berada pada tanaman tersebut. Bila jumlah serangga herbivor banyak ditemukan pada suatu tanaman, maka hal ini juga memungkinkan untuk keberadaan semut predator. Beberapa jenis semut predator yang ditemukan dalam penelitian ini yakni $O$. denticulata, $O$. similimus, $A$. gracilipes dan $O$. minangkabau.

\section{Kelimpahan Semut Berdasarkan Metode Pengambilan Sampel}

Semut dikoleksi menggunakan tiga metode yakni Bait trap, Hand collecting dan Pitfall trap. Pada metode Bait trap didapatkan sebanyak 3.464 individu, 15 spesies dan 9 genus, Hand collecting sebanyak 3.795 individu, 25 spesies dan 11 genus dan Pitfall trap sebanyak 1.504 individu, 19 spesies dan 12 genus (Tabel 2).

Berdasarkan Tabel 2 dapat dilihat bahwa kelimpahan dan keanekaragaman pada setiap metode yang digunakan berbeda-beda. Metode Hand collecting merupakan metode yang paling banyak mengoleksi semut seperti $A$. Gracilipes, $C$. borneensis dan $O$. Denticulata dikarenakan spesies tersebut memiliki koloni yang cukup banyak dan ukurannya yang besar dibandingkan spesies lainnya, sehingga memudahkan dalam menangkapnya. $A$. gracilipes ditemukan sebagai spesies yang dominan serta spesies semut invasif yang mampu mengurangi 
populasi keberadaan spesies semut lokal yang ada sebelumnya. Menurut (Wielgoss et al., 2013), keberadaan spesies semut invasif pada suatu ekosistem dapat mengancam keanekaragaman hayati lokal. Berdasarkan penelitian Hill et al., (2003), $A$. gracilipes dapat memengaruhi komunitas invertebrata lain bahkan beberapa diantaranya mengalami kepunahan.

Tabel 2. Kelimpahan semut berdasarkan metode pengambilan sampel

\begin{tabular}{|c|c|c|c|c|}
\hline Genus & Spesies & ${ }^{*} \mathrm{Bt}$ & ${ }^{*} \mathrm{Hc}$ & ${ }^{*} \mathrm{Pt}$ \\
\hline Anoplolepis & gracilipes Smith, 1857 & 806 & 1814 & 136 \\
\hline \multirow[t]{2}{*}{ Camponotus } & arrogans Smith,1858 & 3 & 49 & 0 \\
\hline & kutteri Forel, 1915 & 0 & 1 & 0 \\
\hline \multirow[t]{3}{*}{ Crematogaster } & borneensis Andre, 1896 & 577 & 630 & 23 \\
\hline & longipilosa Forel, 1907 & 133 & 357 & 52 \\
\hline & rogenhoferi Mayr, 1879 & 0 & 117 & 1 \\
\hline Diacamma & geometricum Smith, 1857 & 0 & 0 & 2 \\
\hline Dolichoderus & affinis Emery, 1889 & 0 & 0 & 1 \\
\hline Leptogenys & aspera Andre, 1889 & 0 & 36 & 76 \\
\hline Monomorium & floricola Jerdon, 1851 & 908 & 27 & 0 \\
\hline Nylanderia & nylanderia sp01 Emery, 1906 & 0 & 0 & 2 \\
\hline \multirow[t]{2}{*}{ Odontomachus } & minangkabau Satria , Kurushima, Herwina, Yamane \& Eguchi, 2015 & 0 & 11 & 44 \\
\hline & similimus Smith, 1858 & 1 & 28 & 29 \\
\hline \multirow[t]{2}{*}{ Odontoponera } & denticulata Smith, 1858 & 11 & 393 & 434 \\
\hline & transversa Smith, 1857 & 0 & 48 & 51 \\
\hline Oecophylla & smaragdina Fabricius, 1775 & 24 & 89 & 0 \\
\hline \multirow[t]{6}{*}{ Pheidole } & upeneci Forel, 1913 & 159 & 68 & 492 \\
\hline & aglae Forel, 1913 & 0 & 2 & 0 \\
\hline & fervens Smith, 1858 & 6 & 11 & 0 \\
\hline & incerta Smith, 1863 & 346 & 31 & 10 \\
\hline & inornata Eguchi, 2001 & 0 & 3 & 57 \\
\hline & sayapensis Eguchi, 2001 & 480 & 13 & 87 \\
\hline \multirow[t]{4}{*}{ Polyrhachis } & abdominalis Smith, 1858 & 1 & 27 & 1 \\
\hline & alphena Smith, 1860 & 0 & 1 & 0 \\
\hline & amana Smith, 1861 & 1 & 0 & 0 \\
\hline & illaudata Walker, 1859 & 8 & 27 & 2 \\
\hline \multirow[t]{3}{*}{ Tetraponera } & laeviceps Smith, 1859 & 0 & 1 & 0 \\
\hline & polita Ward, 2001 & 0 & 10 & 4 \\
\hline & rufonigra Jerdon, 1851 & 0 & 1 & 0 \\
\hline
\end{tabular}

${ }^{*}$ Keterangan $\mathrm{Bt}=$ Bait trap $\mathrm{Hc}=$ Hand collecting, $\mathrm{Pt}=$ Pitfall trap

C. borneensis banyak ditemukan pada pakupakuan dan gulma disekitaran tanaman kelapa sawit, dan $O$. denticulata merupakan spesies semut tanah yang memiliki sarang dan hidup di dalam tanah di sekitar perkebunan, sehingga sangat mudah untuk menangkapnya secara langsung. Hal inilah yang menyebabkan kelimpahan individu tersebut lebih banyak dibandingkan spesies semut lainnya. Pada metode Bait trap kelimpahan spesies semut tertinggi yakni $M$. floricola dan $A$. gracilipes. Spesies $M$. floricola dan $A$. gracilipes ini memiliki jumlah individu terbanyak karena wilayah pencarian makan yang luas, dan bersifat agresif yang terbilang kuat dalam persaingan mencari sumber makanan dibandingkan dengan semut spesies lain sehingga disebut sebagai predator pemulung karena memangsa berbagai fauna di serasah dan kanopi. Jenis ini ditemukan pada batang dan daun dari berbagai spesies pohon dan semak dalam areal perkebunan (Latumahina dkk., 2014). Pada metode Pitfall trap kelimpahan spesies semut tertinggi yakni $P$. upeneci dan $O$. denticulata. Spesies tersebut merupakan semut tanah atau memiliki sarang di dalam tanah di sekitar tanaman kelapa sawit sehingga spesies tersebut lebih dominan didapatkan dengan metode Pitfall trap. 
Jumlah Individu, Spesies dan Indeks Keanekaragaman serta Kemerataan Semut pada Perkebunan Kelapa Sawit Rakyat

Berdasarkan Tabel 3 terlihat bahwa indeks keanekaragaman pada keempat lokasi penelitian berbeda. Pada Nagari Panyubarangan, lahan satu yakni 1,83 dan lahan 2 yakni 2,08. Pada Nagari Tabek, lahan satu yakni 2,08 dan lahan dua yakni 2,06 .

Indeks keanekaragaman dan kemerataan digunakan untuk melihat tinggi atau rendahnya keanekaragaman semut dalam suatu ekosistem. Indeks keanekaragaman yang terdapat pada lahan 2 di Nagari Panyubarangan lebih tinggi dibandingkan lahan 1 dikarenakan jumlah individu yang ada pada lahan 2 lebih banyak daripada lahan 1, berbeda halnya dengan Nagari Tabek, dimana jumlah spesies yang terdapat pada lahan 1 lebih banyak daripada lahan 2. Indeks keanekaragaman semut pada penelitian ini termasuk ke dalam kategori sedang yaitu $>1$ dan $<3$. Indeks keanekaragaman semut pada ekosistem ini sedang disebabkan karena komunitas semut pada ekosistem ini disusun oleh banyak individu dengan kelimpahan individu yang hampir sama bahkan hanya beberapa spesies saja yang dominan sehingga keanekaragaman jenisnya sedang.

Tabel 3. Jumlah spesies (S), jmlah individu (N), indeks dominansi (D), indeks keanekaragaman (H'), dan indeks kemerataan (E) semut pada lokasi penelitian.

\begin{tabular}{lcccc}
\hline \multirow{2}{*}{\multicolumn{1}{c}{ Parameter }} & \multicolumn{2}{c}{ Panyubarangan } & \multicolumn{2}{c}{ Tabek } \\
\cline { 2 - 5 } & Lahan 1 & Lahan 2 & Lahan 1 & Lahan 2 \\
\hline Jumlah Spesies & 19 & 19 & 23 & 21 \\
Jumlah Individu & 2230 & 2276 & 2313 & 1944 \\
Indeks Dominansi & 0,25 & 0,14 & 0,19 & 0,18 \\
Indeks Keanekaragaman & 1,83 & 2,08 & 2,08 & 2,06 \\
Indeks Kemerataan & 0,32 & 0,42 & 0,34 & 0,37 \\
\hline
\end{tabular}

Odum (1996) menyatakan keanekaragaman identik dengan kestabilan suatu ekosistem, yaitu jika keanekaragaman suatu ekosistem relatif tinggi, maka kondisi ekosistem tersebut cenderung stabil. Lingkungan ekosistem yang memiliki gangguan keanekaragaman cenderung sedang, pada kasus lingkungan ekosistem yang yang buruk keanekaragaman jenis cenderung rendah. Indeks keanekaragaman semut ini termasuk kedalam kategori sedang yaitu $>1$ dan $<3$, hal ini sesuai dengan yang diungkapkan oleh Kreb (1989), dimana kriteria indeks keanekaragaman dibagi dalam 3 kategori yaitu: $H^{\prime}<1$ : Keanekaragaman rendah, $1<\mathrm{H}^{\prime}<3$ : Keanekaragaman sedang, $\mathrm{H}^{\prime}>3$ : Keanekaragaman tinggi.

\section{Indeks Nilai Penting (INP) Semut Pada Ekosistem Perkebunan Kelapa Sawit}

Indeks Nilai Penting (INP) semut pada ekosistem kelapa sawit memiliki nilai yang beragam berkisar antara 0,01 sampai dengan 0,57. Dari total 29 spesies terdapat 3 spesies yang memiliki nilai INP tertinggi yakni $A$. graciliphes, $C$. borneensis, dan $M$. floricola (Tabel 4).

A. gracilipes merupakan Spesies yang memiliki nilai INP tertinggi, hal ini disebabkan spesies ini merupakan salah satu spesies invasif yaitu jenis semut yang masuk kehabitat baru dan menguasai habitat tersebut. Spesies invasif dapat menggantikan atau mengurangi kelimpahan semut yang ada sebelumnya sehingga secara perlahan akan merubah interaksi biologis serta fungsi dan struktur organisasi dari ekosistem asli (Holldobler \& Wilson, 1990). Jenis semut ini memiliki sifat yang sangat agresif dan juga terlibat dalam pertarungan mematikan serta mampu bergabung dengan koloni semut lainnya. Oleh karena itu, spesies semut ini sangat mudah dan banyak ditemukan di lapangan.

C. borneensis ditemukan disemua lokasi penelitian, spesies ini banyak ditemukan pada gulma harendong bulu (Clidemia hirta) dan paku-pakuan yang terdapat pada semua lokasi penelitian sehinggga menyebabkan spesies ini memiliki jumlah yang banyak dibandingkan spesies lainnya. Selain didukung oleh keberadaan gulma tersebut, semut ini juga memperoleh sumber energi dengan memakan embun madu yang dihasilkan oleh tumbuhan tersebut. $M$. floricola merupakan semut yang juga termasuk kedalam spesies invasif. Spesies ini memiliki kemampuan untuk bertahan hidup pada daerah yang terganggu, kering dan lembab. $M$. floricola merupakan omnivor yang mengonsumsi serangga baik hidup maupun mati, embun madu, buah dan eksudat tanaman serta beberapa jenis makanan yang terdapat pada pemukiman. Sarangnya biasa ditemukan di sela pelepah, pucuk dan bunga gulma harendong bulu. 
Tabel 4. Indeks nilai penting semut pada perkebunan kelapa sawit rakyat

\begin{tabular}{|c|c|c|c|c|c|}
\hline \multirow{3}{*}{ Genus } & \multirow{3}{*}{ Spesies } & \multicolumn{4}{|c|}{ Indeks Nilai Penting } \\
\hline & & \multicolumn{2}{|c|}{ Panyubarangan } & \multicolumn{2}{|c|}{ Tabek } \\
\hline & & Lahan 1 & Lahan 2 & Lahan & $1 \quad$ Lahan 2 \\
\hline Anoplolepis & gracilipes Smith, 1857 & 0,57 & 0,30 & 0,46 & 0,34 \\
\hline \multirow[t]{2}{*}{ Camponotus } & arrogans Smith,1858 & 0,00 & 0,01 & 0,04 & 0,01 \\
\hline & kutteri Forel, 1915 & 0,00 & 0,00 & 0,01 & 0,00 \\
\hline \multirow[t]{3}{*}{ Crematogaster } & borneensis Andre, 1896 & 0,08 & 0,33 & 0,14 & 0,38 \\
\hline & longipilosa Forel, 1907 & 0,06 & 0,13 & 0,11 & 0,15 \\
\hline & rogenhoferi Mayr, 1879 & 0,00 & 0,12 & 0,01 & 0,03 \\
\hline Diacamma & geometricum Smith, 1857 & 0,00 & 0,00 & 0,00 & 0,01 \\
\hline Dolichoderus & affinis Emery, 1889 & 0,00 & 0,00 & 0,00 & 0,01 \\
\hline Leptogenys & aspera Andre, 1889 & 0,12 & 0,01 & 0,10 & 0,05 \\
\hline Monomorium & floricola Jerdon, 1851 & 0,15 & 0,21 & 0,16 & 0,11 \\
\hline Nylanderia & nylanderia sp01 Emery, 1906 & 0,00 & 0,00 & 0,00 & 0,01 \\
\hline \multirow[t]{3}{*}{ Odontomachus } & minangkabau Satria , Kurushima, & 0,01 & 0,01 & 0,03 & 0,11 \\
\hline & $\begin{array}{l}\text { Herwina, Yamane \& Eguchi, } \\
2015\end{array}$ & & & & \\
\hline & similimus Smith, 1858 & 0,04 & 0,03 & 0,06 & 0,04 \\
\hline \multirow[t]{2}{*}{ Odontoponera } & denticulata Smith, 1858 & 0,22 & 0,16 & 0,27 & 0,19 \\
\hline & transversa Smith, 1857 & 0,04 & 0,04 & 0,06 & 0,09 \\
\hline Oecophylla & smaragdina Fabricius, 1775 & 0,09 & 0,00 & 0,04 & 0,00 \\
\hline \multirow[t]{6}{*}{ Pheidole } & upeneci Forel, 1913 & 0,20 & 0,23 & 0,05 & 0,00 \\
\hline & aglae Forel, 1913 & 0,00 & 0,00 & 0,02 & 0,00 \\
\hline & fervens Smith, 1858 & 0,02 & 0,01 & 0,02 & 0,01 \\
\hline & incerta Smith, 1863 & 0,13 & 0,00 & 0,09 & 0,07 \\
\hline & inornata Eguchi, 2001 & 0,03 & 0,03 & 0,01 & 0,02 \\
\hline & sayapensis Eguchi, 2001 & 0,09 & 0,19 & 0,09 & 0,14 \\
\hline \multirow[t]{4}{*}{ Polyrhachis } & abdominalis Smith, 1858 & 0,02 & 0.04 & 0,05 & 0,06 \\
\hline & alphena Smith, 1860 & 0,01 & 0,00 & 0,00 & 0,00 \\
\hline & amana Smith, 1861 & 0,00 & 0,00 & 0,01 & 0,00 \\
\hline & illaudata Walker, 1859 & 0,02 & 0,02 & 0,06 & 0,06 \\
\hline \multirow[t]{3}{*}{ Tetraponera } & laeviceps Smith, 1859 & 0,01 & 0,00 & 0,00 & 0,00 \\
\hline & polita Ward, 2001 & 0,00 & 0,04 & 0,01 & 0,02 \\
\hline & rufonigra Jerdon, 1851 & 0,00 & 0,01 & 0,00 & 0,00 \\
\hline
\end{tabular}

\section{SIMPULAN}

Total semut yang dikoleksi selama penelitian di Kecamatan Timpeh, Nagari Panyubarangan dan Tabek sebanyak 8.763 individu yang terdiri dari 14 genus, dan 29 spesies. Indeks keanekaragaman di Nagari Panyubarangan pada lahan 1 yakni 1,83 dan pada lahan 2 yakni 2,08, sedangkan di Nagari Tabek pada lahan 1 yakni 2,08 serta pada lahan 2 yakni 2,06. Spesies yang paling dominan adalah $A$. gracilipes dengan Indeks Nilai Penting (INP) yakni 0,57. A. gracilipes merupakan spesies terbanyak dibandingkan dengan spesies lainnya.

\section{DAFTAR PUSTAKA}

Alamsari, W. 2014. Keanekaragaman Semut Pada Berbagai Tipe Penggunaan Lahan di Jambi [Skripsi]. Bogor : Institut Pertanian Bogor.

Antwiki. 2017. Antwiki. Available : http://www.antwiki.org/wiki/indonesia. [30 April 2018].

Badan Pusat Statistik Dharmasraya. 2016. Produksi Kelapa Sawit Perkebunan Rakyat 20152016. Pulau Punjung: Dharmasraya [Diakses 29 Agustus 2019].

Badan Pusat Statistik Provinsi Sumatera Barat. 2017. Produksi Kelapa Sawit Perkebunan Rakyat 2007-2017. Available: Sumbar BPS.go.id. [14 Juni 2019]. 
Bruhl, CA. 2008. No Ark For Ants: Species Loss of Ground-dwelling Forest Ants in Oil Palm Plantations in Sabah, Malaysia (Borneo). http://www.unikoblenzlandau.de/campuslandau/faculty7/e nvironmentalsciencesecotoxicologyenviron ment/staff/terr-ecotox/carstenbruehl/hob/poster-atbc-08. [14 Mei 2018].

Bruhl CA dan KE Linsenmair. 1998. Stratification of ants (Hymenoptera, Formicidae) in primary forest on Mount Kinabalu, Sabah Malaysia. Tropical Ecology, 14: 285-297.

Corley, RHV, and PB Tinker. 2003. The Oil Palm. 4th Ed. Oxford (GB): Blackwell Science.

Departemen Pertanian. 2013. Informasi Ringkas Komoditas Perkebunan. Jakarta : Departemen Pertanian.

Drescher, J, H Feldhaar, and N Bluthgen. 2011. Interspecific aggression and resource monopolization of the invasive ant Anoplolepis gracilipes in Malaysian Borneo. Biotropica 43(1): 93-99.

Falahudin, I. 2013. Peranan semut rangrang (Oecophylla smaragdina). Hal 2604-2618. Di dalam: Pengendalian Biologis Pada Perkebunan Kelapa sawit. Prosiding Konferensi AICIS XII.

Fitria, N. 2013. Komunitas Semut pada Bunga Jantan Kelapa Sawit di Kebun Cimulang di PTPN VIII Bogor Jawa Barat. [Skripsi]. Departemen Biologi Fakultas Matematika dan Ilmu Pengetahuan Alam Institut Pertanian Bogor.

Fricke, TB. 2008. Prarencana Laporan dan Rekomendasi Strategi Pembangunan Minyak Kelapa Sawit Berkelanjutan untuk Aceh Green. Jakarta.

Gibb, H, and DF Hochuli. 2003. Colonisation by a dominant ant facilitated by anthropogenic disturbance: effects on ant assemblage composition, biomass and resource use. Oikos. 103:469-478.

Hill, M, K Holm, T Vel, NJ Shah, and P Matyot. 2003. Impact of the introduced yellow crazy ant Anoplolepis gracilipes on Bird Island, Seychelles. Biodiversity Conservation 12: 1969-1984.

Holldobler, B, and I Wilson. 1990. The Ants. Cambridge Massachusetts: Harvard Univ.

Holway, DA, L Lach, AV Suarez, ND Tsutsui, and TJ Case. 2002. The causes and consequences of ant invasions. Annual Review of Ecology and Systematics. 33:181-233.
Kalshoven, LGE. 1981. The Pests Crops in Indonesia. Laan, P.A. van der, penerjemah. Jakarta : Ichtiar Baru-van Hoeve. Terjemahan dari: De Plagenvan de Culturagewasseen in Indonesie.701 p.

Latumahina, FS. 2011. pengaruh alih fungsi lahan terhadap keanekaragaman semut alam Hutan Lindung Gunung Nona Ambon. Jurnal Agroforestri. 6(1): 18-22.

Latumahina, FS, Musyafa, Sumardi, dan NS Putra. 2014. Kelimpahan dan keragaman semut dalam Hutan Lindung Sirimau Ambon. Jurnal Biospecies. 7(2): 53- 58.

Marshall, T. 2013. Oil Palm Plantations Leave Ants Isolated.

http://planetearth.nerc.ac.uk/news/story.asp x?id=1391. [14 Mei 2018].

Odum, EP. 1996. Dasar-dasar Ekologi. Edisi Ketiga. Yogyakarta. Gajah Mada University Press.

Perfecto, I, and J Vandermeer. 2002. Quality of agroecological matrix in a tropical montane lansdscape: ants in coffee plantations in Southern Mexico. Conserv Bio. 16(1):174182.

Philpott, SM, I Perfecto, I Armbrecht, and CL Parr. 2010. Ant diversity and function in disturbed and changing habitats. In Lach, L, CL Parr KL Abbott (eds). Ant ecology. Oxford University Press. pp. 137- 156.

Riyanto. 2007. Kepadatan, pola distribusi, dan peranan semut pada tanaman di sekitar lingkungan tempat tinggal. Jurnal Penelitian Sains. 10 (2): 241- 250.

Rubiana, R. 2014. Pengaruh Transformasi Habitat Terhadap Keanekaragaman dan Struktur Komunitas Semut di Jambi [Tesis]. Bogor : Institut Pertanian Bogor.

Simanjuntak, D, TAP Rozziansha, Sudarto, A Sipayung, RD Chenon, AE Prasetyo, and A Susanto. 2011. Informasi Organisme Pengganggu "Setothosea asigna van Eecke". Medan : Pusat Penelitian Kelapa Sawit.

Suhara. 2009. Semut Rangrang (Oecophylla smaradigna).

http://file.upi.edu/Direktori/FPMIPA/Jur._P end.Biologi/196512271991031Suhara/Semut -Rangrang_PPT_Entomologi.pdf. [12 April 2018].

Tawatao, NB. 2014. Basic Biology and Ecology of Ants. http://www. antbase. net/english/ants-of-southeastasia/ecology/basic-antbiology.html. 
Wielgoss, A, T Tscharntke, A Rumede, B Fiala, H Seidel, S Shahabudin, and Y Clough. 2013. Interaction complexity

Disentangling services and matters: disservice of ant communities driving yield in tropical agroecosystem. Proceeding of The Royal Society. 281 pp. 